Murawski, T. (2018). CSR in American banking sector. Copernican Journal of Finance \& Accounting, 7(1), 35-50. http://dx.doi.org/10.12775/CJFA.2018.003

\author{
Tomasz Murawski* \\ Nicolaus Copernicus University in Toruń
}

\title{
CSR IN AMERICAN BANKING SECTOR
}

Keywords: corporate social responsibility, bank, banking sector, reporting.

J E L Classification: G21, M14, G15.

\begin{abstract}
Corporate social responsibility has become a natural feature of the banking sector. One of the first, which began to adhere to the CSR policy was the American market. They have looked for many positive correlations between finance, the environment and society. Unfortunately, the slogans do not always go hand in hand with deeds. Sometimes it happens that even the most successful institutions will fall on the CSR path. This article aims to bring the viewpoint of CSR in the US banking sector and will allow to verify the hypothesis of the growing importance of CSR reporting in recent years and also the existing dissonance between reporting information and current activity. The article presents examples of banks that are very much involved in all socially responsible areas, but the author also cites black pages of the CSR history of these institutions. The author reviewed the portfolio of the surveyed banks in terms of compliance with the CSR objectives. The analysis is based on banks' reports on sustainable development, global reports of international organizations, which take care subject-matter of social responsibility, sustainable development or ethics. Based on the analysis of the activities of the surveyed banks and observing the increase in the number of ESG reports and the diverse form of communication of the effectiveness of activities of individual banks, it should be emphasized that a positive trend related to the positive impact of CSR on the financial sector is noticeable.
\end{abstract}

Date of submission: May 9, 2018; date of acceptance: June 3, 2018.

* Contact information: murawski.tomasz@gmail.com, Department of Finance Management, Faculty of Economic Sciences and Management, Nicolaus Copernicus University in Toruń, Gagarina 13a, 87-100 Toruń, Poland, phone: +48 889307 510; ORCID ID: http://orcid.org/0000-0003-1240-8313. 


\section{INTRODUCTION}

Today's world faces many challenges. The American economy, despite many problems at the national level and the changing global environment, remains the largest in the world. According to recent forecasts, nominal GDP will exceed USD 201 billion in 2018. The American economy accounts for approximately $20 \%$ of total global production. The US economy is characterized by a highly developed and technologically advanced services sector, including financial services (Fortune, 2018).

The American banking sector was one of the first, where socially responsible practices were implemented. In recent years, he has undergone many perturbations. Despite the passage of several years since the financial crisis of 2008, a still small percentage of Americans - 27\% (Brunswick, 2016, p. 5) has confidence in banks. Financial institutions from the collapse of Lehman Brothers have radically changed the approach to stakeholders. The article will present the current CSR policy of the largest banks in the United States. At the same time, the author will present the presentation of the topic in the entire sector along with the presentation of how the approach to reporting has changed.

\section{THE RESEARCH METHODOLOGY AND THE COURSE OF THE RESEARCH PROCESS}

The purpose of this article is to present an approach to the topic of corporate social responsibility by top US banks. This article reviews literatures on the banking sector and CSR activities. The analysis is based on banks' reports on sustainable development, global reports of international organizations, which take care subject-matter of social responsibility, sustainable development or ethics. The author reviewed the portfolio of the surveyed banks in terms of compliance with the CSR objectives. This article aims to bring the viewpoint of CSR in the US banking sector and will allow to verify the hypothesis of the growing importance of CSR reporting in recent years and also the existing dissonance between reporting information and current activity.

The author decided to analyze the US market due to the rapid change of approach in the presentation of CSR activities after the financial crisis. The banking sector, despite previous actions in this area, after losing confidence, had to overhaul the policy of correspondence to stakeholders. Analyzed banks are in the top 10 in the US in terms of assets. Verification of their approach to CSR will allow to look at the micro-scale activities of the financial sector in this area. The 
author will include positive and negative examples in the study to present a holistic approach to the subject. Due to editorial requirements, two banks will be subject to analysis in order to learn about different approaches to the topic.

\section{BANKING SECTOR IN UNITED STATES OF AMERICA}

The US banking sector is based on a two-tier model, i.e. a central bank and commercial banks. However, the specific nature of the operations of individual institutions makes this market an important point of reference. The most important statement is that, the Federal Reserve was established to serve the public interest (Kulapka, 2005, pp. 63-64).

Scheme 1. The Federal Reserve System

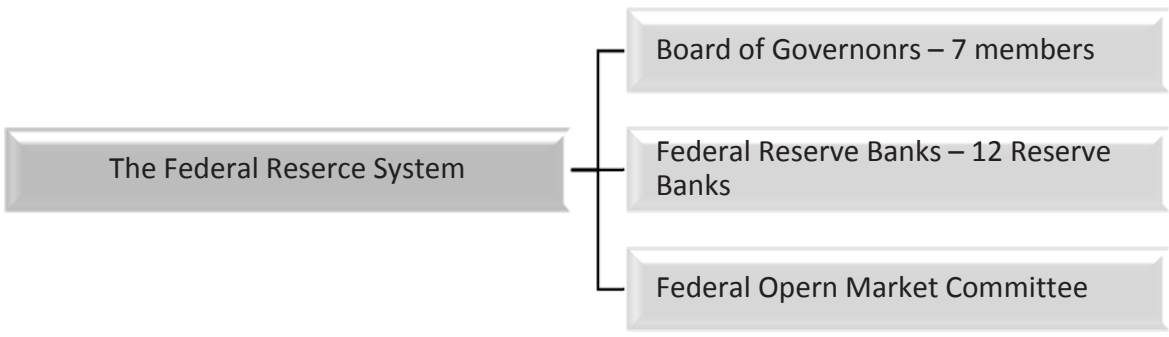

S o u r c e : own work based on: Federal Reserve System Publication, 2016, pp. 8-17.

Currently, the Fed (the Federal Reserve System) is central bank as. The institution, whose roots go back to the 19th century, is responsible for conducting the monetary policy, promoting the stability of the financial system, exercising supervision over banks, fostering payment and settlement system safety and promoting consumer protection. Under to the Federal Reserve Act, which has been modified several times since 1913, was established state body which consists of three organs (Federal Reserve System Publication, 2016, pp. 8-17):

- Board of Governors - consists of seven members elected by the president, decides directly on the level of reserve requirements;

- Federal Reserve Banks - 12 Reserve Banks - these banks are the result of a compromise that has been achieved by the creators of central banking in the United States. They correspond to the 12 districts for which the country is divided, within which they can form a separate policy (cities are: Boston, New York, Philadelphia, Cleveland, Richmond, Atlanta, 
Chicago, St. Louis, Minneapolis, Kansas City, Dallas, San Francisco and Washington, which is the venue for the Board of Governors);

- Federal Open Market Committee - the decisions of this committee are closely monitored by the markets, because by influencing the scale and direction of open market operations it has a large indirect impact on the US lending policy.

Figure 1. Commercial Banks \& Savings Institutions in USA with number of failed Institutions

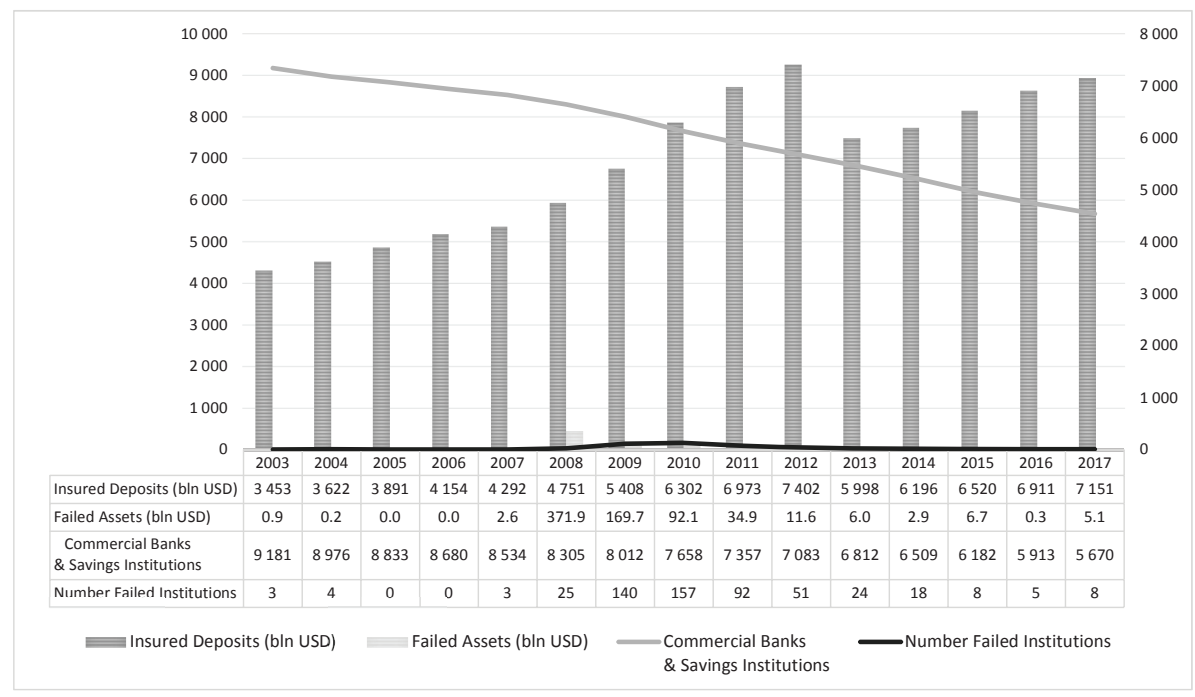

S o u r c e : own work based on: Federal Deposit Insurance Corp, 2018.

The second part of the banking system are commercial banks. The unique feature distinguishing the American market in this area is the significant number of banks operating on this market. These banks may operate under the permission of the state authorities in which they operate (state banks), or operate in accordance with federal law throughout the country (national banks). In accordance with the noticeable tendency of consolidation in the financial markets, one of the key players are bank holding, which bring together institutions operating on behalf of clients in the sphere of finance around one brand. It should be pointed out that they are subject to Fed supervision. In the United States, at the end of 2017, there were 5,670 financial institutions with the status of a commercial bank. This number corresponds to the insured by the US 
government agency, which was created for the purpose of deposit protection. The Federal Deposit Insurance Corp. (FDIC) is the longest-functioning deposit insurance system in the world, operating since 1934, the times of the Great Depression. The system covers funds from banks and savings institutions (Zdanowicz, 2014, pp. 7-31).

\section{CORPORATE SOCIAL RESPONSIBILITY IN US BANKING SECTOR}

Activities in the area of CSR in American banks have been visible for a long time. With the development of the market, the involvement in the non-business sphere of individual sector participants was growing. It is a fact that the economic crisis has forced information on the capital market and non-financial activities, which can be observed after the number of published reports, and on the other hand, the sources of this change should be found in changing the attitudes of both managers and clients.

Figure 2. Number of reports submitted to GRI from USA in 2013-2017

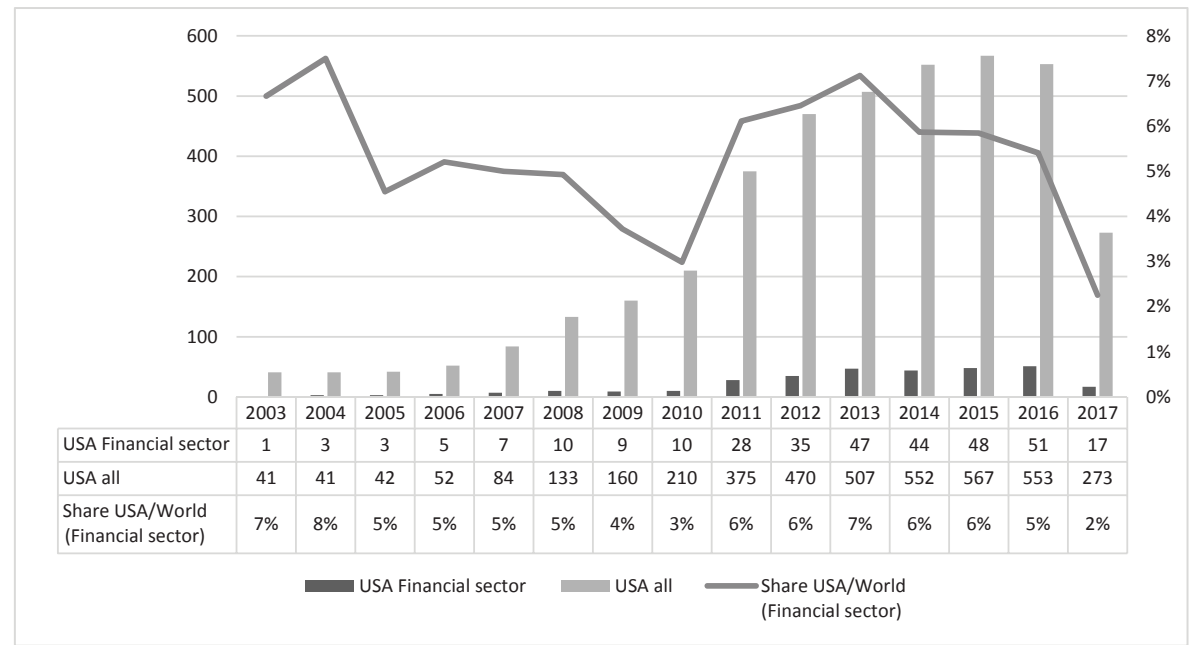

S o u r c e : own work based on: GRI's Sustainability Disclosure Database, 2018.

Reporting and measuring of CSR is one of the area of engagement in CSR. Companies build shareholder value in short and long-term perspective by engaging with stakeholders and by taking the impact of business on the environ- 
ment and society. Regulation, stock exchanges and investor pressure drive rate of CSR reporting to higher level. Analyzing the US market is noticeable increases from $87 \%$ to $92 \%$ over two years in CR reporting rate (KPMG, 2017, p. 15). The analysis of reports (e.g. GRI, KPMG) allow for a conclusion that the trend of the share of published reports is satisfactory. There is a significant increase in the number of reports after 2008 in the financial area, which is related to the economic crisis and lesson learned from these experiences. The banking sector cannot ignore ethical premises in its operations. In addition to prudential regulation and observation of the macroeconomic situation, they should be a key factor to act for the satisfaction of all stakeholders (Węcławski, 2013, pp. 226-228).

The current trend, that is globally distributed, is Climate risk reporting. The USA is one of the five countries where the largest companies, including the banking sector, have recognized the climate risk and report it as part of the financial report. American supervision (US Securities \& Exchange Commission) requires in its regulations (KPMG, 2017, p. 6). This is another step in the development of enterprises, including banks. After all, a modern bank is an institution that, as an integral part of society, cares for its proper development. Analyzes the impact of environmental protection on the world of finance and, thanks to behaviors consistent with the idea of socially responsible business, conducts its activities taking into consideration the pro-ecological priorities (Murawski, 2009, pp. 339-341).

Financial institutions support environmental protection in several areas that can be divided into different areas and varying levels of involvement (three degrees). The main areas are sponsorship and education as supporting activities, own eco-economy, financial activities and relationship activities in the field of PR and IR (Dziawgo \& Dziawgo, 2015, pp. 85-87).

Table 1. Top 10 Banks in USA by total assets

\begin{tabular}{|c|l|c|}
\hline \hline Rank & \multicolumn{1}{|c|}{ Company } & Total assets on 31.12.2017 in US\$b \\
\hline \hline 1 & J.P.Morgan Chase \& Co & 2533600 \\
\hline 2 & Bank of America & 2281230 \\
\hline 3 & Wells Fargo \& Co & 1951760 \\
\hline 4 & Citigroup Inc & 1843060 \\
\hline 5 & Goldman Sachs Group & 916787 \\
\hline
\end{tabular}


Table 1. Top 10 Banks in USA by total assets

\begin{tabular}{|c|l|c|}
\hline \hline Rank & \multicolumn{1}{|c|}{ Company } & Total assets on 31.12.2017 in US\$\$ b \\
\hline \hline 6 & Morgan Stanley & 851733 \\
\hline 7 & U.S. Bancorp & 462040 \\
\hline 8 & TD Group US Holding & 380907 \\
\hline 9 & PNC Financial Services & 380768 \\
\hline 10 & Bank of New York Mellon & 371758 \\
\hline \hline
\end{tabular}

S o u r c e : Banks around the World, 2018.

\section{CSR ACTIVITY IN SELECTED AMERICAN BANKS}

\section{Wells Fargo \& Co}

Wells Fargo \& Co is one of largest financial holding in USA. The name Wells Fargo is forever linked with the image of a six-horse stagecoach. The history begins in 1852 when Henry Wells and William Fargo founded company that offered banking express services (buying gold and selling paper bank drafts, delivery of the gold and other goods). Modernly Wells Fargo provides banking, investments, mortgage, and consumer and commercial finance. The company operates in more than 8300 locations and by the internet and mobile banking (Wells Fargo, 2017b, p. 2).

The company's approach to the subject of CSR is already visible in the concept of vision, values and goals. The management wants the vision "We want to satisfy our customers' financial needs and help them succeed financially" (Wells Fargo, 2012, p. 4) to be implemented by every employee every day. These activities must be linked to the values that the company has set out (Wells Fargo, 2012, pp. 6-12):

- What's right for customers - customers are at the center of the company,

- People as a competitive advantage,

- Ethics - determined by the highest standards and activity of Corporate Responsibility Committee,

- Diversity and inclusion,

- Leadership at all levels.

In 2015 Wells Fargo \& Co announced CSR goals in the perspective of 5 years. They are focused on three priorities. Each priority has been divided into three 
areas: products and services (P\&S), culture and business practices (C\&BP), philanthropy (P).

First of goals is diversity and social inclusion.

- P\&S: focusing on creating products that meet customer expectations,

- C\&BP: diversity, respect inclusion and engagement are an integral part of the operational activity of every cell od Well Fargo \& Co.

- P: transfer of 100 million dollars to support critical social needs.

Second priority is economic empowerment.

- P\&S: facilitating access to affordable and responsible products and services,

- C\&BP: support for clients and employees in financial capabilities.

- P: transfer of 500 million dollars to support critical economic needs.

Third priority is environmental sustainability.

- P\&S: offering products and services that will be associated with clean technology and provide ecological solutions,

- C\&BP: increasing environmental efficiency by reducing the negative impact.

- P: transfer of 65 million dollars to support critical environmental needs.

Despite the development of goals for 2020, the company didn't stop at annual reporting of progress, but also recognized its activities in the areas described by Sustainable Development Goals. They created a map that visually illustrates the state of engagement (Wells Fargo, 2017a, p. 1).

Table 2. Wells Fargo \& Co - goal achievement status

\begin{tabular}{|c|c|c|}
\hline Diversity and social inclusion & Economic empowerment & Environmental sustainability \\
\hline \multicolumn{3}{|c|}{ Products/Services } \\
\hline \multirow[t]{3}{*}{$\begin{array}{l}\text { new mobile app: Daily Change (first } \\
\text { stand-alone personal finance app) } \\
\text { and Wells Fargo Wallet (mobile } \\
\text { wallet) }\end{array}$} & $\begin{array}{l}\text { Over } 4.1 \text { million customers helped } \\
\text { to manage their credit scores and } \\
\text { overall financial health with free } \\
\text { credit score program }\end{array}$ & $\begin{array}{l}\text { More than } 17.6 \text { billion USD in finan- } \\
\text { cing to support renewable energy, } \\
\text { clean technology, and other susta- } \\
\text { inable businesses }\end{array}$ \\
\hline & $\begin{array}{l}12900 \text { low-income homeowners } \\
\text { created through } 327 \text { million USD } \\
\text { in down payment assistance from } \\
\text { Wells Fargo NeighborhoodLIFT }{ }^{\circledR} \text { and } \\
\text { other retired LIFT programs since } \\
2012\end{array}$ & \\
\hline & $\begin{array}{l}49 \text { billion USD in mortgages provi- } \\
\text { ded to minority and low- to modera- } \\
\text { te-income households }\end{array}$ & \\
\hline
\end{tabular}


Table 2. Wells Fargo \& Co - goal achievement status

\begin{tabular}{|c|c|c|}
\hline Diversity and social inclusion & Economic empowerment & Environmental sustainability \\
\hline & $\begin{array}{l}525 \text { Habitat for Humanity homes } \\
\text { built and improved for low-income } \\
\text { homeowners, seniors, and veterans }\end{array}$ & \\
\hline & $\begin{array}{l}36.4 \text { million USD donated to advan- } \\
\text { ce diversity and social inclusion, the } \\
\text { development of women and other } \\
\text { diverse leaders, and other critical } \\
\text { social needs }\end{array}$ & \\
\hline \multicolumn{3}{|c|}{ Culture \& Business Practices } \\
\hline $\begin{array}{l}42 \% \text { of employers in USA is ethnical- } \\
\text { ly/racially diverse }\end{array}$ & $\begin{array}{l}206300 \text { people reached through } \\
\text { Hands on Banking }{ }^{\circledR} \text { financial edu- } \\
\text { cation workshops (non-commercial } \\
\text { program that teaches people in va- } \\
\text { rious stages of life about the basics } \\
\text { of responsible money management) }\end{array}$ & $\begin{array}{l}36 \% \text { reduction in absolute greenho- } \\
\text { use gas emissions since } 2008\end{array}$ \\
\hline $56 \%$ of global workforce are women & $\begin{array}{l}\text { Over } 1200 \text { hours of free tax as- } \\
\text { sistance provided to low-income } \\
\text { families by team member volunteers } \\
\text { through } 68 \text { Volunteer Income Tax } \\
\text { Assistance programs nationwide }\end{array}$ & $\begin{array}{l}52 \% \text { increase in water efficiency } \\
\text { since } 2008\end{array}$ \\
\hline $\begin{array}{l}2 \text { million hours volunteered by } \\
\text { employers }\end{array}$ & & $\begin{array}{l}31 \% \text { increase in energy efficiency } \\
\text { since } 2008\end{array}$ \\
\hline \multirow[t]{2}{*}{$\begin{array}{l}13 \% \text { increase in volunteer group } \\
\text { participation over start the strategy }\end{array}$} & & $\begin{array}{l}21 \% \text { of total square footage in le- } \\
\text { ased and owned buildings is LEED }{ }^{\circledR} \\
\text {-certified }\end{array}$ \\
\hline & & $\begin{array}{l}58600 \text { hours volunteered in envi- } \\
\text { ronmental projects }\end{array}$ \\
\hline \multicolumn{3}{|l|}{ Philantropy } \\
\hline $\begin{array}{l}36.4 \text { million USD donated to } \\
\text { advance diversity and social } \\
\text { inclusion, the development } \\
\text { of women and other diverse } \\
\text { leaders, and other critical } \\
\text { social needs }\end{array}$ & $\begin{array}{l}87.9 \text { million USD donated to support } \\
\text { financial education, sustainable } \\
\text { housing, small businesses, and other } \\
\text { critical economic needs }\end{array}$ & $\begin{array}{l}15.6 \text { million USD donated to } \\
\text { support nonprofits, universities, } \\
\text { and community organizations } \\
\text { focused on environmental } \\
\text { sustainability, clean technology, } \\
\text { environmental education, and } \\
\text { strengthening community } \\
\text { resiliency }\end{array}$ \\
\hline $\begin{array}{l}\text { More than } 100 \text { million USD in } \\
\text { grants and home donations } \\
\text { to support military veterans } \\
\text { since } 2012\end{array}$ & & \\
\hline
\end{tabular}

S o u r c e : Wells Fargo, 2016; www1. 
A very important area in which Well Fargo \& Co implemented the CSR premises is risk management. The Environmental and Social Risk Management (ESRM) policy applies a coherent approach to understanding, assessing and integrating environmental and social risks in the decision-making process at every level of management and operations. This ESRM policy has been entirely based on the company's historical operations and has been adapted to its characteristics. ESRM policy is aligned with international industry standards:

- Carbon Principles - require banks to assess the risks associated with greenhouse gas emissions associated with financing coal-fired power plants in the USA. Wells Fargo adopted the Carbon Principles in 2008,

- Equator Principles - Those Principles are a framework established by the industry to determine, assess, and manage social and environmental risks and impacts associated within energy projects (power plants, solar plants, dams, oil and gas exploration). Wells Fargo adopted the Equator Principles in 2005 (Wells Fargo, 2015, pp. 3-4).

Presenting the company's activities at the CSR level, it is impossible to omit black history cards. In the case of Wells Fargo \& Co, you can find several cases that do not match the above-described posture. Analyzing the last years, one can point out several scandals that have come to light, and are related to this bank.

The first case should be the September 2016 issue. It was announced that the bank created 3.5 millions of unauthorized bank and credit card accounts without their customers knowing it. The bank was punished with 185 million USD. In addition, over 5300 employees were dismissed. They were accused by the bank of causing this incident. One of the explanations given by employees was the extensive bonus system that promoted such behaviors (Egan, 2016).

Another issue is the accusation of modifying mortgages without the permission of the clients. This means that some customers could pay more to the bank than they were owed. The case was disclosed in July 2017. In the same month there were reports of irregularities in the offering of auto insurance. The bank acknowledged that it had charged at least 570000 customers for auto insurance, which they did not need. Wells Fargo reported that an internal audit showed that around 20,000 customers could have defaulted in car loans for similar reasons. The accumulation of these allegations resulted in legal steps that led to a change at the top management levels of Wells Fargo \& Co. In February 2018, the Fed punished the bank. The punishment is very painful and includes an overview of the entire management board and that it will not be 
able to increase its assets until these ethical problems are resolved. In February 2018, the Fed punished the bank. The punishment is very painful and includes an overview of the entire management board and that it will not be able to increase its assets until these ethical problems are resolved (Wattles, Geier \& Egan, 2018).

\section{U.S. BANCORP}

History of the U.S. Bankcorp begins in the 19th century. In 1863 was founded the First National Bank of Cincinnati. It was one of the founding banks. This regional bank grew stronger and over the years, new branches and many other new regional banks have emerged. After a series of M\&A was established in 1968 the First Bank System - new financial holding. Further development, subsequent acquisitions and a change in strategy meant that in September 1997, the U.S. Bankcorp brand appeared on the market. Today, it is the seventh largest bank in the US in terms of assets (U.S. Bankcorp, 2018).

Analyzing the bank's activity in terms of socially responsible activities, it should be stated that it is being taught in an orderly and consistent manner in this area. Confirmation of the above statement may be actions in the area of ESG, which are currently one of the key processes in CSR policy. As Reba Dominski, Chief Social Responsibility Officer, pointed out "Environmental, Social, Governance - An Integrated Part of How We do Business. In the year ahead, we will focus on our Environmental, Social and Governance efforts and getting better every day by listening and learning from key stakeholders" (U.S. Bankcorp, 2017a).

Table 3. U.S. Bancorp - ESG activities

\begin{tabular}{|l|l|l|}
\hline \multicolumn{1}{|c|}{ Environmental } & \multicolumn{1}{c|}{ Social } & \multicolumn{1}{c|}{ Governance } \\
\hline \hline $\begin{array}{l}\text { Ecovolunteering - U.S. Bank has } \\
\text { more than 30 employee green } \\
\text { teams. They are responsible for } \\
\text { sustainable volunteering activities } \\
\text { throughout the company }\end{array}$ & $\begin{array}{l}\text { 2018 Forbes Best Employers for } \\
\text { Diversity List - recognition of multi- } \\
\text {-faceted activities in the area of } \\
\text { diverse workplace }\end{array}$ & $\begin{array}{l}\text { Public Responsibility Committee - } \\
\text { oversight committee on the policy } \\
\text { issues of CSR and environmental } \\
\text { sustainability. }\end{array}$ \\
\hline $\begin{array}{l}\text { GHG goal - to reducing operational } \\
\text { greenhouse gas (GHG) emissions by } \\
\text { 40\% by 2029 and 60\% by 2044 (the } \\
\text { reference point is 2014) }\end{array}$ & $\begin{array}{l}\text { Human Rights Campaign's (HRC) } \\
\text { Corporate Equality Index - score of } \\
\text { 100 for 11 year in a row }\end{array}$ & $\begin{array}{l}\text { Diversity - 42\% of the managerial } \\
\text { staff are women or people of color }\end{array}$ \\
\hline
\end{tabular}


Table 3. U.S. Bancorp - ESG activities

\begin{tabular}{|c|c|c|}
\hline Environmental & Social & Governance \\
\hline $\begin{array}{l}\text { Climate change disclosure-A-score } \\
\text { in } 2016 \text { and } 2017\end{array}$ & $\begin{array}{l}\text { Best for Vets Employer for } 8 \text { year in } \\
\text { a row - the "Military Times" perce- } \\
\text { ive action for veterans }\end{array}$ & $\begin{array}{l}\text { Awards: } \\
\text { - the Most Trusted Companies for } \\
\text { Retail Banking by the Ponemon } \\
\text { Institute for the } 11 \text { year in a row, } \\
\text { - the World's Most Ethical Compa- } \\
\text { nies }{ }^{\circledR} \text { Ethisphere }{ }^{\circledR} \text { Institute for the } \\
4 \text { year in a row } \\
\text { - the Most Admired Superregional } \\
\text { Bank by FORTUNE for the } 4 \text { year } \\
\text { in a row. } \\
\text { - } 2017 \text { CSR Leadership Award }\end{array}$ \\
\hline $\begin{array}{l}\text { UNSDG - environmental commit- } \\
\text { ments align closely to the United } \\
\text { Nations Sustainable Development } \\
\text { Goals }\end{array}$ & $\begin{array}{l}\text { Growth of employee engagement } \\
\text { - in } 2017 \text { over } 15000 \text { employees } \\
\text { belonged to one of } 10 \text { Business } \\
\text { Resource Groups ( } 40 \% \text { increase over } \\
\text { 2016) }\end{array}$ & \\
\hline
\end{tabular}

S o u r c e : U.S. Bankcorp, 2017c.

The main slogan that heads the entire corporate socially responsible business of U.S. Bancorp is "Community Possible". This password is related to the bank's approach to CSR and is also a program that has been operating globally since 2016. It combines the involvement of bank employees as part of volunteering, cooperation with NGOs and the foundation that coordinates some of the initiatives (U.S. Bankcorp, 2016, pp. 2-10).

Activities in this area can be divided into several categories. The first is charitable giving. It is reflected in the activities of the U.S. Bank Foundation, Corporate Giving, program Dollars for Doing and Employee Matching Gift Program. Bank Foundation donated 26.2 million USD to various types of grants and charitable purposes. In 2016, U.S. Bank contributed 28 million USD in corporate philanthropic initiatives or nonprofit sponsorships. The Dollary for Doing program supports volunteers in their work for NGOs. Every hour worked by a volunteer is equivalent to USD 5 for charitable purposes.

Another area is Community Development. Through the services and products of the U.S. Bankcorp supports various communities. It meets their various needs, helps to ensure the economic and social foundations of life. As part of this program, there are special loans that are targeted at low- and middle-income individuals and families.

Another example of corporate social responsibility is employee volunteering. Bank encourages and supports employee through the U.S. Bank Volunteers 
program. Over the last three years, U.S. Bank employees shared their skills and knowledge through more than one million hours of volunteer service with a variety of NGOs. Each employee may work 16 hours as part of his normal duties for a non-governmental organization of his choice.

Financial education is one of the key programs supported by U.S. Bankcorp. As part of the Financial Genius platform, they offer tools that help them make informed financial decisions and create projections of every investment path or credit. As part of this education, it is possible to obtain a scholarship for students in the amount of 20000 USD.

Last but not least important area is environmental protection. Last but not least important area is environmental protection. The bank promotes sustainable business practices. Over the past few years, he has invested over 15.5 billion dollars. US Bankcorp applies environmental policy to its operation. These principles help ensure compliance with best practices in the field of sustainable development. Ecological solutions are promoted in all of their activities:

- In 2016, they invested over USD 1.5 billion in renewable energy. It corresponded to supplying over 300,000 homes with energy,

- The reduction of carbon dioxide emissions from these investments equals the removal of 445,000 vehicles from the roads,

- Community Solar Gardens - an investment of 300,000 houses powered by renewable energy. The project will provide access to solar energy for those who do not have a proper roof, do not have a home or business, residents in multi-family buildings and low-income residents,

- Build new branch locations in accordance with Leadership in Energy and Environmental Design (LEED) standards. Until now 21 branches with LEED certification (U.S. Bankcorp, 2017a; U.S. Bankcorp, 2016; U.S. Bankcorp, 2017b).

The above examples are the image of a bank strongly committed to responsible business. In the next part, the author will quote the unethical behavior that took place in Bankcorp's activity. In February 2018 U.S. Bancorp agreed to pay the federal government $\$ 613$ million. Punishment is the result of failure to apply appropriate safeguards in anti-money laundering policy. On the basis of the federal investigation, it turned out that the bank omitted suspicious transactions for a period of five years from 2009 to 2014. After the incident, the American CEO and president of Bancorp, Andy Cecere, said in a statement that the company "assumed responsibility for the past shortcomings in 
our program [counteracting money laundering] Our culture of ethics and integrity requires us to do better" (Spencer, 2018).

\section{CONCLUSIONS}

The banking sector in recent years has significantly remodeled in terms of approach and communication in the area of corporate social responsibility. Analysis of the portfolio of banks and their involvement in shaping the surrounding environment, which makes us speak about the growing impact of the sector on the environment. Observing the increase in ESG reports or the diverse form of communication of the effectiveness of activities of individual banks, it should be pointed out that a positive trend is noticeable. Analyzed banks have won awards for socially responsible companies for many years in a row. This situation confirms the tenednet that a sound management approach allows CSR activities at every stage of the company's operations. Initiatives are of particular importance for the beneficiaries, who constitute the basic winnings in the entire activity. Changes in the awareness of ordinary employees begin with the approach of top management. Unfortunately, despite the titles of the most ethical companies, the banking sector has not avoided unflattering examples. The described cases of negative CSR are a warning to all market participants to take care of a responsible approach to each stage of their business at every step. The quoted illustrations of negative behaviors have been bolded to give a fair look at the subject of corporate social responsibility.

\section{REFERENCES}

Banks around the World (2018). The Largest Banks in the United States, http://www. relbanks.com/top-us-banks/assets (accessed: 15.04.2018).

Brunswick (2016). Biannual Financial Services Barometer. October 2016, http:// www.brunswickgroup.com/media/3254/brunswickfigbarometerwave2deckoctober2016v2-161005192316.pdf (accessed: 15.04.2018).

Dziawgo, L., \& Dziawgo, D. (2015). Selected Aspects of CSR in the Financial Market Survey Results on a Representative Sample of Polish Society. In G. Borys, R. Kurek (Eds.). Finanse i rachunkowość na rzecz zrównoważonego rozwoju: odpowiedzialność, etyka, stabilność finansowa. Tom 1: Finanse. Nr 395. (Finance and accounting for sustainable development: responsibility, ethics, financial stability. Volume 1: Finance. Issue 395.) Wrocław: Research Papers of the Wroclaw University of Economics. http:// dx.doi.org/10.15611/pn.2015.395.08. 
Egan, M. (2016). I called the Wells Fargo ethics line and was fired, http://money.cnn. com/2016/09/21/investing/wells-fargo-fired-workers-retaliation-fake-accounts/ index.html (accessed: 15.04.2018).

Federal Deposit Insurance Corp (2018). Statistics at a Glance, http://www.fdic.gov/ bank/statistical/stats/index.html (accessed: 14.04.2018).

Federal Reserve System Publication (2016). The Federal Reserve System. Purposes \& Functions. Tenth Edition. Washington. http://dx.doi.org/10.17016/0199-9729.10.

Fortune (2018). The World's Top 10 Largest Economies, http://www.focus-economics. com/blog/the-largest-economies-in-the-world (accessed: 14.04.2018).

GRI's Sustainability Disclosure Database (2018). GRI Research data, http://database. globalreporting.org/search (accessed: 14.04.2018).

KPMG (2017). The road ahead. The KPMG Survey of Corporate Responsibility Reporting 2017.

Kulapka, P. (2005). Banking System in the United States. Zeszyty naukowe Kolegium Gospodarki Światowej, 18, 63-80.

Murawski, T. (2009). Responsible banking, that is, banks act in accordance with the principles of Corporate Social Responsibility. In K. Brzozowska, S. Flejterski (Eds.). Finanse 2009. Teoria i praktyka. Bankowość. (Finance 2009. Theory and practice. Banking.) Szczecin: Wydawnictwo Naukowe Uniwersytetu Szczecińskiego.

Spencer, J. (2018). Feds fine U.S. Bancorp $\$ 613$ million for failing to guard against money-laundering, http://www.startribune.com/feds-fine-u-s-bancorp-613-millionfor-money-laundering-violations/474188183 (accessed: 15.04.2018).

U.S. Bankcorp (2016). CSR Report 2016, http://www.usbank.com/en/corporate_responsibility/US_Bank_2016_CSR.pdf (accessed: 15.04.2018).

U.S. Bankcorp (2017a). CSR Report 2017, http://www.usbank.com/en/CSR-Annual-Report-2017/index.html (accessed: 15.04.2018).

U.S. Bankcorp (2017b). U.S. Bank Sustainability Facts 2017, http://www.usbank.com/ pdf/community/US-Bank-Sustainability-Factsheet.pdf (accessed: 15.04.2018).

U.S. Bankcorp (2017c). CSR Report 2017, http://www.usbank.com/en/CSR-Annual-Report-2017/index.html (accessed: 15.04.2018).

U.S. Bankcorp (2018). About U.S. Bank, http://www.usbank.com/about-us-bank.html (accessed: 15.04.2018).

Wattles, J., Geier, B., \& Egan, M. (2018). Wells Fargo's 17-month nightmare, http://money.cnn.com/2018/02/05/news/companies/wells-fargo-timeline/index.html (accessed: 15.04.2018).

Wells Fargo (2012). The Vision \& Values of Wells Fargo, http://www.damicofcg.com/ files/74720/Vision\%20\%26\%20Values.pdf (accessed: 15.04.2018).

Wells Fargo (2015). Wells Fargo Environmental and Social Risk Management 2015, http://www.wellsfargo.com/assets/pdf/about/corporate-responsibility/environmental_lending_practices.pdf (accessed: 15.04.2018).

Wells Fargo (2016). Corporate Social Responsibility Interim Report 2016, http://www. wellsfargo.com/assets/pdf/about/corporate-responsibility/2016-social-responsibility-interim.pdf (accessed: 15.04.2018). 
Wells Fargo (2017a). Wells Fargo Alignment Map 2017, http://www.wellsfargo.com/assets/pdf/about/corporate-responsibility/sustainable-development-goals.pdf (accessed: 15.04.2018).

Wells Fargo (2017b). Wells Fargo Today, http://www.wellsfargo.com/assets/pdf/ about/corporate/wells-fargo-today.pdf (accessed: 15.04.2018).

Węcławski, J. (2013). Large Banks and their Role in the Financial Crisis. Annales Universitatis Mariae Curie-Skłodowska, sectio H - Oeconomia, 47(1), 219-228.

Zdanowicz, B. (2014). The US Approach to Bank Restructuring - the Federal Deposit Insurance Corporation (FDIC) Experience. Bezpieczny Bank, (54), 7-31.

(www1) Wells Fargo - 2017 Corporate Social Responsibility Report, http://www. wellsfargo.com/about/corporate-responsibility/goals-and-reporting (accessed: 15.04.2018). 